Review

\title{
Applicability of International Harvesting Equipment Productivity Studies in Maine, USA: A Literature Review
}

\section{Patrick Hiesl and Jeffrey G. Benjamin *}

School of Forest Resources, University of Maine, 5755 Nutting Hall, Orono, ME 04469, USA; E-Mail: patrick.hies1@maine.edu

* Author to whom correspondence should be addressed; E-Mail: jeffrey.g.benjamin@maine.edu; Tel.: +1-207-581-2727.

Received: 12 July 2013; in revised form: 14 September 2013 / Accepted: 11 October 2013 / Published: 5 November 2013

\begin{abstract}
Harvesting equipment productivity studies have been conducted in many countries around the world spanning over 25 years. These studies have shown that many factors influence individual machine productivity. These factors include stand and site conditions, equipment configuration, management objectives, and operator experience. Productivity can increase or decrease with slight changes in any of these factors. This literature review also highlights the variety of experimental designs and data collection methods encountered in a cross section of those studies. It further shows the variation in species composition, stand density, tree diameter, and harvest prescription. Although studies that include the influence of operator performance on harvest equipment productivity are limited, they were included in this review where appropriate and available. It is clear that productivity equations should be developed using population-level data with several operators. Some studies were conducted in stands similar to Maine, but they used harvesting equipment that is not commonly used in logging operations in this state. Therefore the applicability of existing studies to the logging industry in Maine, USA, is very limited. Our conclusion is that in order to accurately predict harvesting productivity it is necessary to develop regional harvesting productivity equations using harvesting equipment commonly used in Maine. Forest operations researchers in other regions will be able to use this summary to explore the difficulty of applying productivity information to regional logging operations.
\end{abstract}


Keywords: logging; operator effect; feller-buncher; harvester; grapple skidder; forwarder; mechanized harvest

\section{Introduction}

It has been over 25 years since machine-level productivity studies have been conducted in Maine, USA, so there is a need to assess the applicability of such research from other regions. Many countries including Canada and Germany use detailed numbers to estimate cost and productivity of harvesting operations. These data are available from government agencies and forestry research institutes. Further, accuracy of machine rate calculations have been and will be improved in Europe to meet the needs of the logging industry [1,2]. Research studies in Italy [3,4], France and Finland [5], and some parts of the United States [6-9] use similar approaches in methods and analysis of their data to develop machine rates, and productivity and cost functions for their logging equipment with respect to site and forest conditions. This type of research allows stakeholders in the logging industry to accurately predict logging costs and benchmark their productivity to regional averages.

Logging equipment such as feller-bunchers, harvesters, and forwarders are expensive to own and operate. With high investment costs it is important to efficiently manage a logging business to ensure profitability. Such management, however, can only be achieved with up-to-date information on harvest productivity and cost. This information needs to be available for all machines in harvesting systems to accurately plan harvest activities and to support operational decision making. Holzleitner et al. [10] reported similar thoughts and also elaborated that the monitoring of economic variables can be difficult. Wang et al. [8] reported that many loggers were hesitant to commit to high investment costs of a harvesting system due to lack of confidence that the system would produce enough volume to be profitable. This highlights the importance of accurate productivity and cost information to support loggers in their decision making of acquiring new equipment.

Through personal experience of the authors it is known that logging contractors in Maine have identified the need for productivity and cost information. Some have started to keep detailed records of their own equipment. A variety of data tracking systems have been developed by the contractors from simple spreadsheets to very sophisticated databases. Innovative contractors also developed software extensions on handheld personal digital assistants (PDA) to track more detailed time and production data on every piece of equipment [11]. Regardless of the level of sophistication of the tracking systems, collecting and managing such data is time consuming and expensive. Further, these data are not shared within the industry, rather they are held confidentially within each logging company for internal use and planning purposes.

The objective of this paper is to outline the variability and range of influential factors of harvesting productivity of studies from other regions with the intent of assessing applicability of those studies to Maine's logging industry. This paper will compare site and operation conditions from other studies (e.g., species mixture, slope, prescription, dbh range) to conditions in Maine and then discuss the challenges of using productivity models from other regions in Maine's logging industry. 


\section{Background on Maine's Logging Industry}

Maine is the most forested state in the nation with the greatest percentage of forest cover. In fact, approximately 7.1 million ha, or $82 \%$ of the total land area is forested [12,13]. Forest-based manufacturing is the largest manufacturing industry in Maine and it contributed $36 \%$ of Maine's total manufacturing sales to the economy in 2005 [12]. Total revenue from Maine's forest in 2005 was $\$ 6.47$ billion or $\$ 916.58$ per forested hectare [12]. This shows the importance of the forest industry in Maine. Effective management in combination with accurate productivity and cost information is necessary to further optimize and strengthen the logging industries contribution to Maine's economy.

The Maine Forest Service [14] reported that in 2011 a total of 177,735 ha were harvested. Partial and shelterwood harvests were prescribed on more than $95 \%$ of the total area that was harvested. A survey by Leon and Benjamin [15] reported that $93 \%$ of the volume harvested in 2011 was by whole-tree (80\%) and cut-to-length (13\%) systems. The remaining 7\% are harvested by conventional full tree harvesting systems consisting of a forest worker with a chainsaw and a cable skidder. A whole-tree harvesting system usually consists of a feller-buncher, grapple skidder, and stroke delimber. The feller-buncher cuts trees at the stump and piles the trees in a bunch. Following that, bunches are transported by the grapple skidder to roadside, where the stroke delimber removes the branches and crowns. A cut-to-length harvesting system usually consists of a harvester and forwarder. The harvester cuts the trees at the stump and processes the trees into logs. Branches and crowns are used as brush mats for the harvester and forwarder. The forwarder collects the logs and forwards them to the roadside where they are piled.

The northern hardwood forest type (Acer saccharum Marshall, Betula alleghaniensis Britt., Fagus grandifolia Ehrh.), is the most common forest type in Maine and covers 2.8 million ha (41\%), followed by the spruce/fir (Picea rubens Sarg., Abies balsamea (L.) Mill.), aspen/birch (Populus tremuloides Michx., Populus grandidentata Michx,, Betula papyrifera Marshall, Acer rubrum L.) and white/red pine (Pinus strobus L., Pinus resinosa Sol. ex Aiton) forest types (Figure 1) [12]. Since species composition is closely related to regeneration strategy (i.e., plantation or natural), it is not surprising that stand origin in Maine is $97.9 \%$ from natural regeneration and only $2.1 \%$ from plantations [16].

Figure 1. Common forest types in Maine (re-drawn from North East State Foresters Association [12]).

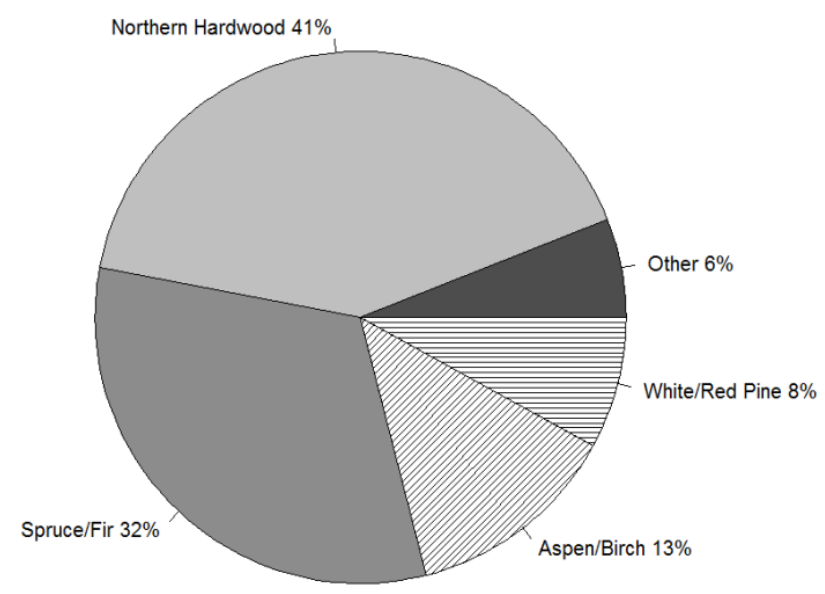


Landownership in Maine is unique for the region in that $93 \%$ is classified as private forest ownership [13]. Businesses (corporate and investors) own 57\% of Maine forests, while 33\% is owned by families and individuals, and $3 \%$ by other private entities; Federal, state and local ownership account for the remaining 7\%. There are 233,000 families and individuals that own forest land in Maine. Two thirds of these own parcels of 1 to 10 acres. Harvesting timber is not the primary reason for owning family forests; however, two thirds of the forest owners have commercially harvested their holdings.

\section{Machine Productivity}

Numerous studies have been conducted throughout the world over the last 25 years regarding the productivity of harvesting equipment. Table 1 summarizes a cross section of 27 of these studies in terms of machine type, geographic location, slope, harvest prescription, stem size, stand density, and findings of influential factors on productivity. There has not been a single study of this nature published in peer-reviewed literature from Maine during this time. Some of the studies chosen were conducted close to Maine and therefore are more likely to reflect the site and stand conditions common to this region.

Table 2 shows a summary of the productivity range from numerous studies for four commonly used pieces of equipment (harvester, forwarder, feller-buncher, grapple skidder). Differences in productivity are due to a variety of reasons, such as tree size. Harvester productivity conducted in a clear cut by Jiroušek et al. [17] with a fairly large stem size $\left(0.1 \mathrm{~m}^{3}-1.0 \mathrm{~m}^{3}\right)$ resulted in a productivity of 13.5 to $60.5 \mathrm{~m}^{3} / \mathrm{PMH}$ (Productive Machine Hour). This study used three different harvesters ranging from $80 \mathrm{hp}$ (horse power) to $150 \mathrm{hp}$, which may account for some of the variation in productivity. Légère and Gingras [18], also working in a clear-cut, included stand densities ranging from 530-1700 trees per ha, which in combination with smaller stem size, led to a lower productivity of 12.9 to $13.7 \mathrm{~m}^{3} / \mathrm{PMH}$. The harvester they studied was a John Deere 690ELC which is rated with a gross power of $140 \mathrm{hp}$. Other studies, such as Glöde [19], and Gingras and Favreau [20], were conducted in thinning operations with smaller stem sizes which resulted in a wide range of productivity $\left(9.7\right.$ to $\left.34.0 \mathrm{~m}^{3} / \mathrm{PMH}\right)$. Glöde's [19] study included two harvesters (i.e., Valmet 892/960 and Valmet 892/955), but there was no information available for the harvester studied by Gingras and Favreau [20]. Lanford and Stokes [21] reported an average harvester productivity of $21.0 \mathrm{~m}^{3} / \mathrm{PMH}$ using a Valmet 546 Woodstar harvester. The variation in the make, model, and gross power of the harvesters studied clearly impacts the harvester productivity in combination with other factors such as tree size.

Forwarder productivity ranges from 7.9 to $17.0 \mathrm{~m}^{3} / \mathrm{PMH}[18,20-22]$. An exception to this was reported by Jiroušek et al. [17] with forwarder productivity reaching as high as $40 \mathrm{~m}^{3} / \mathrm{PMH}$. This increase was attributed to large stem volume (up to $1 \mathrm{~m}^{3}$ ) and short forwarding distances which started at $80 \mathrm{~m}$. Another contributing factor to the increased productivity was the fact that three different forwarders with engines ranging from $90 \mathrm{hp}$ to $140 \mathrm{hp}$ and payload capacities of smaller than ten tonnes to greater than twelve tonnes were studied. Forwarding distances of other studies ranged from $150 \mathrm{~m}$ to $365 \mathrm{~m}$ using forwarders such as Valmet 5446 Woodstar, Timberjack 1010, or Rottne Rapid [18,21,22]. Payload capacity of forwarders also affects the productivity [17]. Small payload capacities in combination with long forwarding distances explain the low productivity seen in some 
studies $[17,21,22]$. Clearly multiple factors such as forwarding distance, payload capacity, and log size play important roles in determining forwarder productivity $[4,7,17,23]$.

Differences in productivity have also been found for feller-bunchers. Andersson and Evans [24] reported by far the highest productivity among the selected studies $\left(37.8-117.7 \mathrm{~m}^{3} / \mathrm{PMH}\right)$. They harvested trees with an average dbh of $22 \mathrm{~cm}$ to $36 \mathrm{~cm}$, in a 100 to 130 year old aspen stand. The high tree volume ranging from $0.32 \mathrm{~m}^{3}$ to $0.97 \mathrm{~m}^{3}$, within a stand density of 210 to 540 trees per ha, further explains the high feller-buncher productivity in their study. Further, they included three different machines in their study (Timberjack 618, John Deere 790 and Prentice 630). Phillips [25] clearcut old-growth softwood stands with a Caterpillar 325 feller-buncher with average stem volumes of $0.1 \mathrm{~m}^{3}-0.4 \mathrm{~m}^{3}$ and achieved rather low productivity of 6.4 to $10.1 \mathrm{~m}^{3} / \mathrm{PMH}$. Productivity values from other studies of feller-bunchers were within the range of 20-30 $\mathrm{m}^{3} / \mathrm{PMH}[18,21,26]$ and used models such as Hydro Ax 411, Timbco 445C, Koehring 618, Koehring 625, or John Deere 693 [8,21,22,26].

Grapple skidder productivity is greatly influenced by the skidding distance [8,27]. Wang et al. [8] reported the greatest range in skidding distance from $60 \mathrm{~m}$ to $970 \mathrm{~m}$ which resulted in productivity ranges from 4.0 to $67.1 \mathrm{~m}^{3} / \mathrm{PMH}$. Andersson and Evans [24] reported high grapple skidder productivity ranging from 29.3 to $78.8 \mathrm{~m}^{3} / \mathrm{PMH}$. The high productivity is due to the short skidding distance of $50 \mathrm{~m}$ to a maximum of $160 \mathrm{~m}$. In their study they used four different skidders (John Deere 748E, Timberjack 380, Timberjack 450C, John Deere 648E). Lanford and Stokes [21] reported an average skidding distance of $194 \mathrm{~m}$ which explains the average productivity of $21.0 \mathrm{~m}^{3} / \mathrm{PMH}$. Their study took place in two thinning operations using a John Deere 640 grapple skidder, while the other studies were conducted in clear cuts. The studies by Phillips [25] and Gingras and Favreau [20] reported skidder productivities of between 6 and $15 \mathrm{~m}^{3} / \mathrm{PMH}$ along with skidding distances of up to $500 \mathrm{~m}$. Average skidding distances were $69 \mathrm{~m}$ [25] and $350 \mathrm{~m}$ [20]. The skidder studied by Phillips [25] was a John Deere $748 \mathrm{G}$.

Stroke delimber productivity has not been widely studied in recent years. As with feller-buncher productivity stroke delimber productivity is dependent on tree size. Andersson and Evans [24] reported stroke delimber productivities ranging from 47.9 to $107.5 \mathrm{~m}^{3} / \mathrm{PMH}$, with averages of 59.4 and $93.8 \mathrm{~m}^{3} / \mathrm{PMH}$ for the two machines studied. Their study included trees of $22 \mathrm{~cm}$ to $36 \mathrm{~cm}$ in diameter and tree volumes between $0.32 \mathrm{~m}^{3}$ and $0.97 \mathrm{~m}^{3}$, which explains the high productivity. The stroke delimbers used were Lim-mit 2200 on a John Deere 892 and Caterpillar 300B carrier, respectively. Phillips [25] used two Pro Pac stroke delimber mounted on a Caterpillar 320 and Hitachi EX200 carrier in their study, respectively. However, no productivity information was reported for the stroke delimber. Gingras [22] studied a Denis telescopic stroke delimber on a Komatsu 200L-3 carrier and reported a productivity of $22.6 \mathrm{~m}^{3} / \mathrm{PMH}$. The lower productivity can be explained by the average volume of the delimbed trees of $0.17 \mathrm{~m}^{3}$ compared to tree volumes up to $0.97 \mathrm{~m}^{3}$ in the Andersson and Evans [24] study. 
Table 1. Reviewed literature and summary of specific harvest information; The applicability of items in the column heading to the individual publications is marked with an "X".

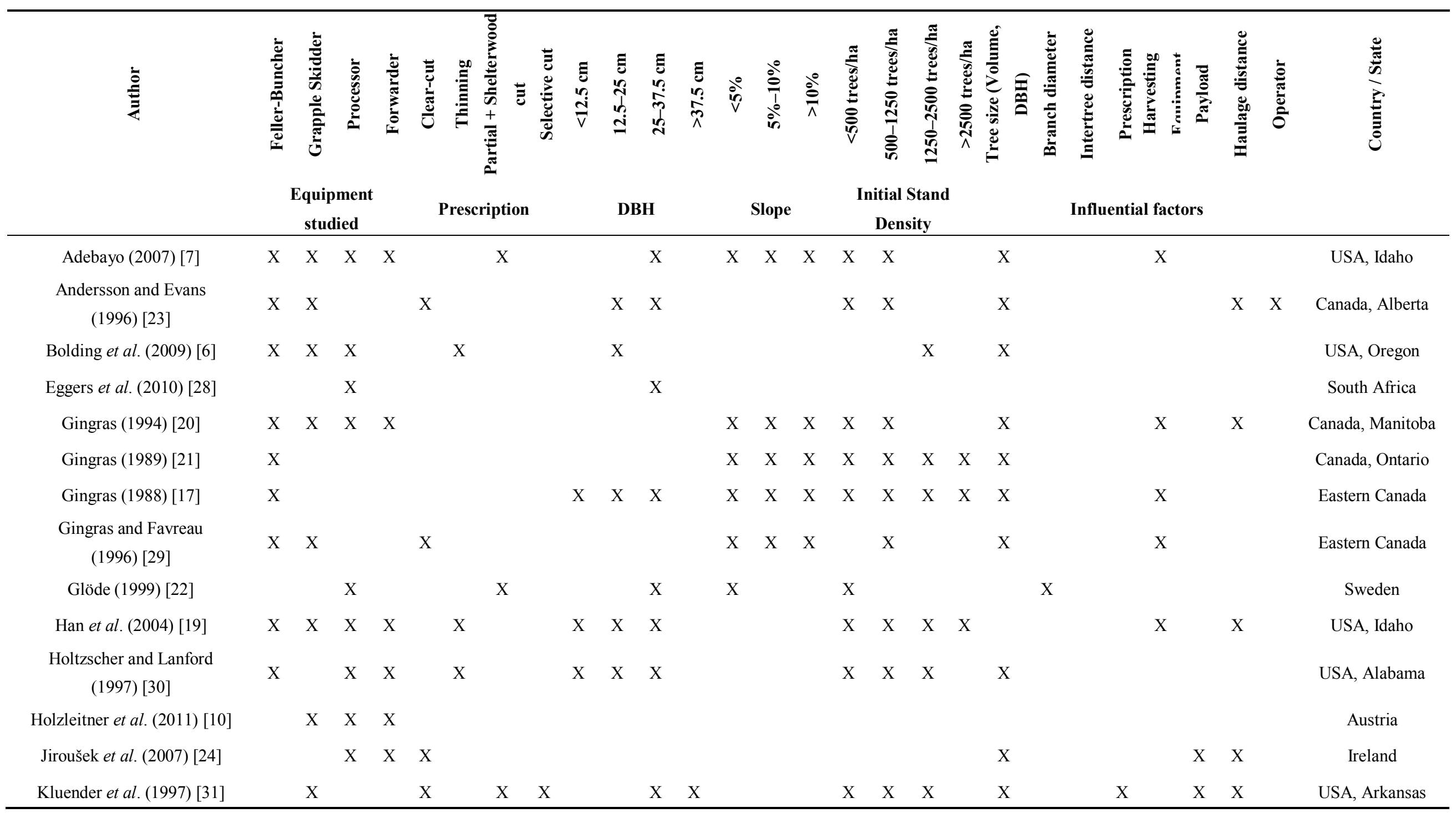


Table 1. Cont.

\begin{tabular}{|c|c|c|c|c|c|c|c|c|c|c|c|c|c|c|c|c|c|c|c|c|c|c|c|c|c|c|c|c|}
\hline$\stackrel{\vec{E}}{\underline{E}}$ & 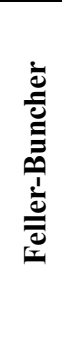 & 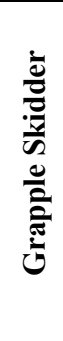 & 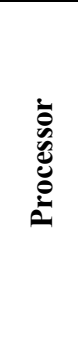 & 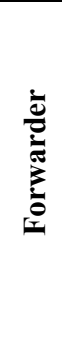 & 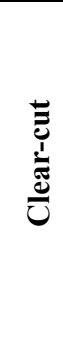 & $\begin{array}{l}0 \\
\\
\end{array}$ & 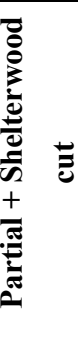 & 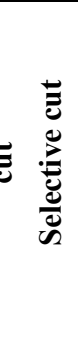 & 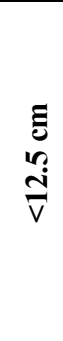 & 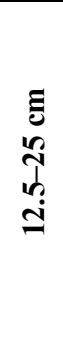 & 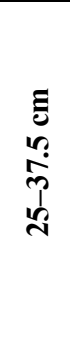 & $\begin{array}{c}\Xi \\
\vdots \\
\stackrel{0}{0} \\
\hat{n}\end{array}$ & ì & $\begin{array}{l}\frac{\partial}{\frac{0}{b}} \\
\frac{\partial}{\partial}\end{array}$ & $\frac{\stackrel{\circ}{\circ}}{\Lambda}$ & 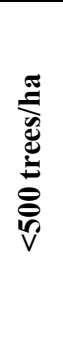 & 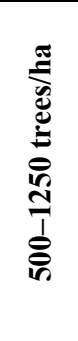 & 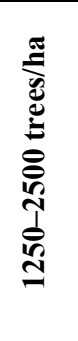 & 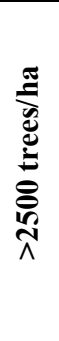 & 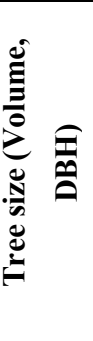 & 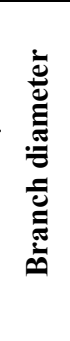 & 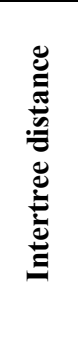 & 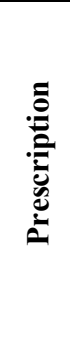 & 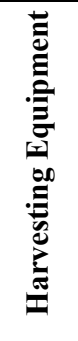 & $\frac{\vec{J}}{\vec{E}}$ & 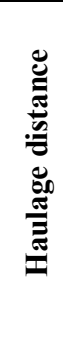 & 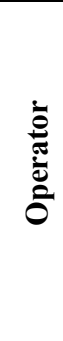 & 总 \\
\hline & Equ & ipme & nt stud & & & Presc & iption & & & $\mathrm{DF}$ & & & & Slope & & & $\begin{aligned} \text { nitial s } \\
\text { Dens }\end{aligned}$ & $\begin{array}{l}\text { Stand } \\
\text { ity }\end{array}$ & & & & Influ & ientia & 1 facto & & & & \\
\hline Lanford and Stokes (1996) [26] & $\mathrm{X}$ & $\mathrm{X}$ & $\mathrm{X}$ & $\mathrm{X}$ & & $\mathrm{X}$ & & & $\mathrm{X}$ & $\mathrm{X}$ & $\mathrm{X}$ & & & & & & $\mathrm{X}$ & & & $\mathrm{X}$ & & & & & & & & USA, Alabama \\
\hline Légère and Gingras (1998) [32] & $\mathrm{X}$ & $\mathrm{X}$ & $\mathrm{X}$ & $\mathrm{X}$ & $\mathrm{X}$ & & & & $\mathrm{X}$ & $\mathrm{X}$ & & & & & & & $\mathrm{X}$ & $\mathrm{X}$ & & & & & $\mathrm{X}$ & $\mathrm{x}$ & & & & Canada, Quebec \\
\hline Nakagawa et al. (2007) [33] & & & $\mathrm{X}$ & & & $\mathrm{X}$ & & & & $\mathrm{X}$ & & & & & $\mathrm{X}$ & $\mathrm{X}$ & & & & $\mathrm{X}$ & & & & & & & & Japan \\
\hline Ovaskainen et al. (2004) [34] & & & $\mathrm{X}$ & & & $\mathrm{X}$ & & & $\mathrm{X}$ & $\mathrm{X}$ & & & & & & & $\mathrm{X}$ & & & $\mathrm{X}$ & & & & & & & $\mathrm{X}$ & Finland \\
\hline Phillips (1997) [35] & $\mathrm{X}$ & $\mathrm{x}$ & & & & & & & & & & & & & & $\mathrm{X}$ & $\mathrm{x}$ & & & & & & & & & & & $\begin{array}{c}\text { Canada, } \\
\text { Saskatchewan }\end{array}$ \\
\hline Purfürst (2010) [36] & & & $\mathrm{X}$ & & & $\mathrm{x}$ & & & & & & & $\mathrm{X}$ & $\mathrm{X}$ & & & & & & & & & & & & & $\mathrm{X}$ & Germany \\
\hline Richardson (1989) [18] & & & $\mathrm{X}$ & & & & & & $\mathrm{X}$ & $\mathrm{X}$ & $\mathrm{X}$ & & $\mathrm{X}$ & $\mathrm{X}$ & $\mathrm{X}$ & & & $\mathrm{x}$ & $\mathrm{X}$ & $\mathrm{X}$ & $\mathrm{x}$ & & & $\mathrm{X}$ & & & $\mathrm{X}$ & Eastern Canada \\
\hline $\begin{array}{l}\text { Richardson and Makkonen } \\
\text { (1994) [37] }\end{array}$ & & & $\mathrm{X}$ & $\mathrm{X}$ & $\mathrm{X}$ & & & & & & & & & & & & & & & $\mathrm{X}$ & $\mathrm{X}$ & & & $\mathrm{X}$ & & $\mathrm{X}$ & $\mathrm{X}$ & Eastern Canada \\
\hline Simões et al. (2008) [27] & & & $\mathrm{X}$ & & & & $\mathrm{X}$ & & & & & & $\mathrm{X}$ & & & & & & & & & & & & & & & Brazil \\
\hline $\begin{array}{c}\text { Spinelli and Magagnotti (2010) } \\
\text { [7] }\end{array}$ & & & $\mathrm{X}$ & $\mathrm{X}$ & & $\mathrm{x}$ & & & & $\mathrm{X}$ & & & & & $\mathrm{X}$ & & $\mathrm{X}$ & & & & & & & & & $\mathrm{X}$ & & Italy \\
\hline Spinelli et al. (2010) [4] & & & $\mathrm{X}$ & & $\mathrm{X}$ & $\mathrm{X}$ & $\mathrm{X}$ & $\mathrm{X}$ & $\mathrm{X}$ & $\mathrm{X}$ & $\mathrm{X}$ & $\mathrm{X}$ & & & & $\mathrm{X}$ & $\mathrm{X}$ & $\mathrm{X}$ & $\mathrm{X}$ & $\mathrm{X}$ & & & & $\mathrm{X}$ & & & $\mathrm{X}$ & Italy \\
\hline Spinelli et al. (2007) [5] & $\mathrm{X}$ & & & & & $\mathrm{X}$ & & & $\mathrm{X}$ & & & & $\mathrm{X}$ & & & & & $\mathrm{X}$ & $\mathrm{X}$ & $\mathrm{X}$ & & & & $\mathrm{X}$ & & & $\mathrm{X}$ & $\begin{array}{l}\text { Finland, Italy, } \\
\text { France }\end{array}$ \\
\hline Wang et al. (2004) [8] & $\mathrm{X}$ & $\mathrm{X}$ & & & $\mathrm{X}$ & & $\mathrm{X}$ & & & $\mathrm{X}$ & $\mathrm{X}$ & $\mathrm{X}$ & $\mathrm{X}$ & $\mathrm{X}$ & $\mathrm{X}$ & $\mathrm{X}$ & $\mathrm{X}$ & & & $\mathrm{X}$ & & $\mathrm{X}$ & & & $\mathrm{X}$ & $\mathrm{X}$ & & $\begin{array}{l}\text { USA, West } \\
\text { Virgina }\end{array}$ \\
\hline
\end{tabular}


Table 2. Summary of productivity results from previous timber harvesting studies.

\begin{tabular}{|c|c|c|c|c|c|}
\hline Author & $\begin{array}{l}\text { Harvester } \\
\mathrm{m}^{3} / \mathrm{PMH} \\
\end{array}$ & $\begin{array}{c}\text { Forwarder } \\
\mathrm{m}^{3} / \mathrm{PMH} \\
\end{array}$ & $\begin{array}{c}\text { Feller- } \\
\text { Buncher } \\
\mathrm{m}^{3} / \mathrm{PMH}\end{array}$ & $\begin{array}{l}\text { Grapple } \\
\text { Skidder } \\
\mathrm{m}^{3} / \mathrm{PMH} \\
\end{array}$ & $\begin{array}{c}\text { Stroke } \\
\text { Delimber } \\
\mathrm{m}^{3} / \mathrm{PMH} \\
\end{array}$ \\
\hline Andersson and Evans (1996) [24] & - & - & $37.8-117.7$ & $29.3-78.8$ & $47.9-107.5$ \\
\hline Gingras (1994) [22] & $16.9-26.7$ & $14.3-14.9$ & 28.0 & 8.7 & 22.6 \\
\hline Gingras (1989) [31] & - & - & $10.4-63.2$ & - & - \\
\hline Gingras (1988) [26] & - & - & $31.0-32.0$ & - & - \\
\hline Gingras and Favreau (1996) [19] & $9.7-11.4$ & $7.9-17.0$ & $25.9-27.9$ & $10.7-15.6$ & - \\
\hline Glöde (1999) [19] & $15.9-34.0$ & - & - & - & - \\
\hline Jiroušek et al. (2007) [17] & $13.5-60.5$ & $8-40$ & - & - & - \\
\hline Lanford and Stokes (1996) [21] & 9.0 & 9.0 & 21.0 & 21.0 & - \\
\hline Lègére and Gingras (1998) [18] & $12.9-13.7$ & $11.5-11.8$ & $21.9-25$ & - & - \\
\hline Phillips (1997) [25] & - & - & $6.4-10.1$ & $6.4-10.1$ & - \\
\hline Richardson (1989) [29] & $4.9-13.1$ & - & - & - & - \\
\hline Wang et al. (2004) [8] & - & - & 36.0 & $4.0-67.1$ & - \\
\hline \multicolumn{6}{|l|}{ Conversions used: } \\
\hline \multicolumn{6}{|c|}{1 cord $=85$ cubic feet of solid wood } \\
\hline 1 cubic foot $=0.028316 \mathrm{~m}^{3}$ & & $1 \mathrm{~m}^{3}=35.3$ & cubic foot & & \\
\hline
\end{tabular}

A wide range of productivities for common harvesting equipment from several different studies were discussed previously in this paper. Many factors, such as tree size, hauling distance, and even machine make/model, influence the productivity of harvesting equipment. Harvesting equipment studied differs from study to study (Table 3). Especially the equipment used for cutting trees (Harvester, Feller-Buncher) varies significantly from equipment used in Maine. Out of seven whole-tree and five cut-to-length harvest sites visited by the authors in 2012 only one used harvesting equipment that was discussed before. That particular harvester, however, had over 14,000 h and is most likely to be replaced in the near future. We acknowledge that some equipment was in the same horse power range as used in today's forest. With the advancement of processing speed and the technological development of equipment, it is difficult to compare equipment productivities from 20 years ago to today's. Applying harvesting productivities to Maine's logging industry therefore proves difficult due to the differences in harvesting equipment employed.

\section{Site and Stand Conditions}

The following sections summarize the variety of stand and site conditions from previous studies and compares them to Maine's forests. The key variables in terms of site and stand conditions are: species composition, stand density, slope, and stem size. The variation within these variables in productivity information from other regions makes their application to Maine challenging. 
Table 3. Summary of model and make of harvesting equipment used in timber harvesting studies.

\begin{tabular}{|c|c|c|c|c|c|}
\hline Author & Harvester & Forwarder & Feller-Buncher & Grapple Skidder & $\begin{array}{c}\text { Stroke } \\
\text { Delimber }\end{array}$ \\
\hline Andersson and Evans (1996) [24] & - & - & $\begin{array}{c}\text { Timberjack } 618 \\
\text { John Deere } 790 \\
\text { Prentice } 630\end{array}$ & $\begin{array}{c}\text { John Deere } 748 \mathrm{E} \\
\text { Timberjack } 380 \\
\text { Timberjack 450C } \\
\text { John Deere 648E }\end{array}$ & $\begin{array}{c}\text { Lim-mit } 2200 \text { on John Deere } 892 \text { and } \\
\text { Caterpillar 300B carriers }\end{array}$ \\
\hline Gingras (1994) [22] & Timberjack 1270 & Timberjack 1010 & Koehring 618 & Clark 665 & $\begin{array}{c}\text { Denis telescopic stroke delimber on } \\
\text { Komatsu 200L-3 carrier }\end{array}$ \\
\hline Gingras (1989) [31] & - & - & $\begin{array}{c}\text { Koehring } 625 \\
\text { John Deere 693D }\end{array}$ & - & - \\
\hline Gingras (1988) [26] & - & - & $\begin{array}{c}\text { John Deere } 693 \\
\text { Timberjack Timbco } 2518\end{array}$ & - & - \\
\hline Glöde (1999) [19] & $\begin{array}{l}\text { Valmet 892/960 } \\
\text { Valmet 892/955 }\end{array}$ & - & - & - & - \\
\hline Jiroušek et al. (2007) [17] & $80 \mathrm{hp}-150 \mathrm{hp}$ & $90 \mathrm{hp}-140 \mathrm{hp}$ & - & - & - \\
\hline Lanford and Stokes (1996) [21] & - & - & Hydro Ax 411 & John Deere 640 & - \\
\hline Légère and Gingras (1998) [18] & John Deere 690ELC & Rottne Rapid & Timberjack 618 & - & - \\
\hline Phillips (1997) [25] & - & - & Caterpillar 325 & John Deere 748G & $\begin{array}{l}\text { Pro Pac stroke delimber on Caterpillar } \\
320 \text { and Hitachi EX200 carriers }\end{array}$ \\
\hline Richardson (1989) [29] & $\begin{array}{c}\text { Bruun } 7610 \mathrm{H} \\
\text { Rottne EGS-85 } \\
\text { Timberjack FMG990 }\end{array}$ & - & - & - & - \\
\hline Wang et al. (2004) [8] & - & - & Timbco 445C hydro-buncher & Timberjack 460 & - \\
\hline
\end{tabular}




\subsection{Species Composition}

Only a few of the studies listed in Table $1[20,26]$ utilized tree species common to this region (i.e., balsam fir (Abies balsamea (L.) Mill.), white spruce (Picea glauca (Moench) Voss), quaking aspen (Populus tremuloides Michx.)). Species specific traits, such as branch thickness affect harvesting productivity [19]. Due to the effect of these traits on equipment productivity the species composition of past studies needs to be carefully scrutinized. As noted earlier, species composition is dependent on regeneration strategy, so Maine's practice of natural regeneration limits the applicability of approximately half of the reviewed studies due to their harvest of plantations. Stand origin in Maine is $97.9 \%$ from natural regeneration and only $2.1 \%$ from plantations [16]. Several of the more recent studies have been conducted in softwood plantations focusing on Norway spruce (Picea abies (L.) H.Karst.) [4,5], Japanese larch (Larix kaempferi (Lamb.) Carr.) [33], Scots pine (Pinus sylvestris L.), European white birch (Betula pubescens Ehrh.), European hornbeam (Carpinus betulus L.), English oak (Quercus robur L.), basswood (Tilia sp. L.) [5], patula pine (Pinus patula Schiede ex Schltdl. \& Cham.), and slash pine (Pinus elliottii Engelm.) [32]. Naturally regenerated stands, as common in Maine, were the focus of few studies and included the harvesting of species foreign to Maine. For example, shortleaf pine (Pinus echinata Mill.) and loblolly pine (Pinus taeda L.) were part of the study by Kluender et al. [38], while Scots pine (Pinus sylvestris L.) was the focus of Ovaskainen et al. [28]. However, tree species common to this region such as balsam fir, red spruce (Picea rubens Sarg.), white pine (Pinus strobus L.), sugar maple (Acer saccharum Marshall), quaking aspen, white birch (Betula papyrifera Marshall), and yellow birch (Betula alleghaniensis Britt.) were only included in a limited number of studies mostly from eastern Canada [18,22,24,25]. Since clear cutting single species plantations is much more productive than thinning naturally regenerated mixed-species stands, one must use caution when applying results from those studies to Maine.

\subsection{Stem Size}

Many published studies reported that stem size (diameter and volume) significantly impacted the productivity of harvesting equipment. Lanford and Stokes [21] reported, that average dbh and basal area per feller-buncher accumulation significantly influenced felling and bunching time per tree, which influenced productivity. Kluender et al. [38] reported dbh as one of the key variables in describing the cycle time and productivity of a feller-buncher. Several other studies concluded that stem size is a significant factor affecting feller-buncher productivity [5,8,20]. Wang et al. [8] further reported that in addition to stem size the total feller-buncher felling time was most affected by the ground travel distance between harvested trees. Stem size also affects the productivity of harvesters as has been reported by Jiroušek et al. [17], Ovaskainen et al. [28], Richardson [29]. Nakagawa et al. [33] reported that harvester productivity is positively affected by an increasing dbh due to the increasing piece volume. A simulation by Li et al. [27] further reported that the harvester was more sensitive to the tree size than the feller-buncher. This is likely due to the effect of increased branch diameter on the delimbing speed of harvesters as reported by Glöde [19]. Nakagawa et al. [33] concluded that only the delimbing time of a harvester was affected by the dbh of the harvested trees. Simões et al. [39] 
reported that $52.3 \%$ of the cycle time of a harvester is taken by the processing part which includes the delimbing, which supports the results of Glöde [19].

Stem size (volume and diameter) depends on a variety of factors. Species and stand density have a great influence on the individual stem size. Stem size reported in previous studies ranges from $3 \mathrm{~cm}$ to $79 \mathrm{~cm}$ in diameter (Table 4), and from $0.03 \mathrm{~m}^{3}$ to $1.29 \mathrm{~m}^{3}$ in volume (Table 5). Reasons for the difference in stem size might be the difference in age of stands, site productivity, stand density, as well as the species composition. The difference between minimum and maximum diameters in individual studies is heterogeneous and ranges from $6 \mathrm{~cm} \mathrm{[19]} \mathrm{to} 61 \mathrm{~cm}$ [8] (Figure 2). Studies that show a range of $1 \mathrm{~cm}$ only published the average diameter harvested but not the full range $[4,6,7]$. Due to a large area of forestland with small diameter trees [13], the diameter range of interest in Maine and this region is from $10 \mathrm{~cm}$ to $33 \mathrm{~cm}$. The majority of the reviewed studies fall within the dbh range of interest, however, only few cover the entire diameter range [3,23,29].

Stem size also affects skidding and forwarding productivity. Grapple skidder productivity is affected by the bunch size that is to be skidded to the road side [8,27]. With larger stem sizes individual bunch size can be increased without increasing feller-buncher traveling distance between cut trees and bunches. An increased traveling distance would negatively impact feller-buncher productivity [8]. Lanford and Stokes [21] reported an average grapple skidder load size of 1.37 tonnes, while Wang et al. reported a range of 0.74 tonnes to 5.35 tonnes (converted from cubic feet to tonnes with a factor of 0.0288 tonnes/cubic foot for hardwoods). In combination with skidding distance this difference in load size also explains the difference in grapple skidder productivity between the two studies. A larger log size will also increase the payload and productivity of forwarders $[17,18]$ as will the timber volume at each loading location [40]. A higher volume per grapple cycle on a forwarder is directly related to productivity [21].

Table 4. Summary of dbh and stand density of timber harvesting studies.

\begin{tabular}{ccc}
\hline Author & $\begin{array}{c}\text { dbh } \\
\text { cm }\end{array}$ & $\begin{array}{c}\text { Stand density } \\
\text { trees per ha }\end{array}$ \\
\hline Andersson and Evans (1996) [24] & $22-36$ & $133-548$ \\
Eggers et al. $(2010)$ [32] & $30-33$ & N/A \\
Gingras (1988) [26] & $12-30$ & $243-3025$ \\
Glöde (1999) [19] & $32-38$ & $183-233$ \\
Han et al. (2004) [23] & $3-38$ & $340-2825$ \\
Holtzscher and Lanford (1997) [35] & $10-28$ & N/A \\
Kluender et al. (1998) [38] & $26-41$ & $318-2203$ \\
Légère and Gingras (1998) [18] & $>10$ & $535-1720$ \\
Nakagawa et al. (2007) [33] & $16-25$ & 488 \\
Ovaskainen et al. (2004) [28] & $13-13$ & $1083-1245$ \\
Spinelli et al. (2010) [3] & $10-42$ & $73-2722$ \\
Spinelli et al. (2007) [5] & $7-10$ & $1898-3945$ \\
Spinelli and Magagnotti (2010) [4] & 18 & $1050-1148$ \\
Wang et al. (2004) [8] & $18-79$ & $490-650$ \\
\hline Conversions used: & & \\
1 cm = 0.3937 inches & 1 in. $=2.54 \mathrm{~cm}$ & \\
1 ha = 2.5 acres & &
\end{tabular}


Table 5. Summary of tree volume and stand density of timber harvesting studies.

\begin{tabular}{ccc}
\hline Author & $\begin{array}{c}\text { Tree volume } \\
\mathbf{m}^{\mathbf{3}}\end{array}$ & $\begin{array}{c}\text { Stand density } \\
\text { trees per ha }\end{array}$ \\
\hline Gingras (1994) [22] & $0.18-0.57$ & $505-1013$ \\
Gingras (1989) [31] & $0.04-0.30$ & $313-2580$ \\
Gingras and Favreau & $0.11-0.14$ & $1113-1265$ \\
$\quad(1996)[20]$ & $0.14-0.41$ & $410-1005$ \\
Phillips (1997) [25] & $0.03-1.29$ & $1923-3338$ \\
Richardson (1989) [29] & & \\
Conversions used: & 1 in. $=2.54 \mathrm{~cm}$ & \\
$1 \mathrm{~m}^{3}=35.315$ cubic feet & & \\
1 ha $=2.5$ acres & &
\end{tabular}

Figure 2. Range of $\mathrm{dbh}$ in harvesting equipment productivity studies. Dashed lines represent the upper and lower diameter limit of research interest in Maine.

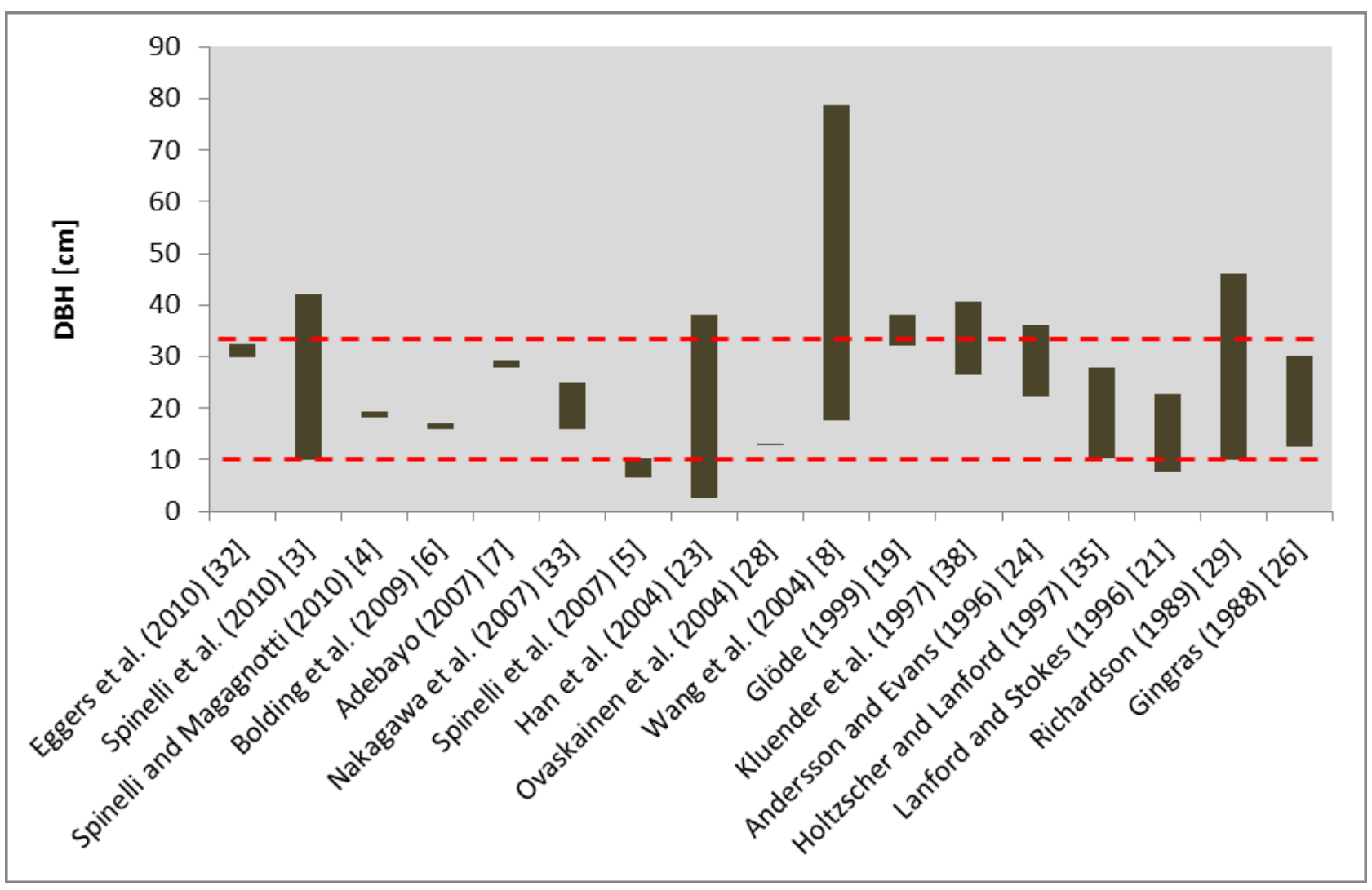

\subsection{Stand Density}

Gingras [26] reported stand density to be one factor that affects the harvesting productivity of a feller-buncher. Several studies reviewed in this paper were conducted in stands with densities less than 1000 trees per hectare [4,7,8,22,24,33], which is well below that observed in Maine (e.g., 1000 to 4800 trees per hectare $[37,41]$ ) (Figure 3). In most cases the lower the stand density, the higher the average stem size (Tables 4 and 5). Although much research has been focused in medium stem size and low density stands, there is a need for more productivity studies in small diameter, high density stands. 
Besides the study by Gingras [26] no other reference was found to support the influence of stand density on harvesting productivity, however, Li et al. [27] reported the prescription as one influential factor. With different stand densities there are differences in prescription which leads to the conclusion that stand density indirectly affects harvest productivity.

Figure 3. Summary of the variation in stand density among several harvesting equipment productivity studies. Dashed red lines represent the upper and lower stand density limits of interest in Maine for whole-tree and cut-to-length harvesting systems.

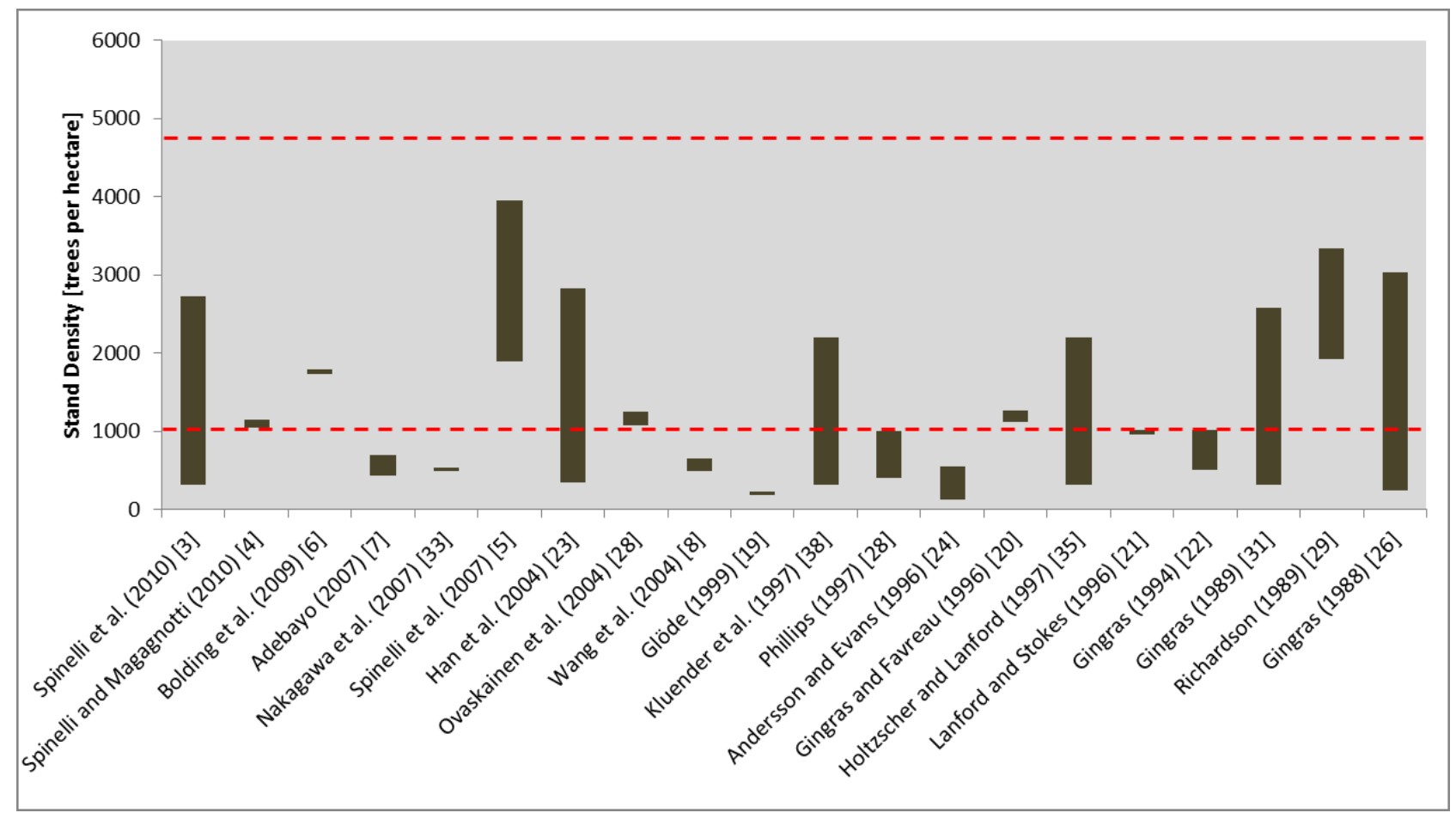

\subsection{Slope}

Another important factor that influences the productivity of harvesting equipment is the slope on which the harvest takes place. Spinelli et al. [3] reported that in addition to significantly limiting accessibility of a stand, slope affects the moving time within the stand. A wide range of slopes have been studied previously, ranging from level ground to slopes of 45\% (Figure 4). The range of slopes studied in the late 1980s and 1990s was greater than it has been in recent years (e.g., [22,26]). Slopes up to $14 \%$, and in one case $17 \%$ to $35 \%$, have been observed by the authors during a harvesting equipment productivity study in Maine. Observations by the authors and communications with logging contractors suggest that slopes less than $15 \%$ are commonly harvested in this region. However, the authors and the forest industry also acknowledge that there are steep slopes in this region for which there is a need of further research on feasibility of harvesting on such terrain. 
Figure 4. Summary of slope gradients of harvesting equipment productivity studies. Dashed red lines represent the upper and lower slope limit of forestland commonly harvested by whole-tree and cut-to-length harvesting systems in Maine.

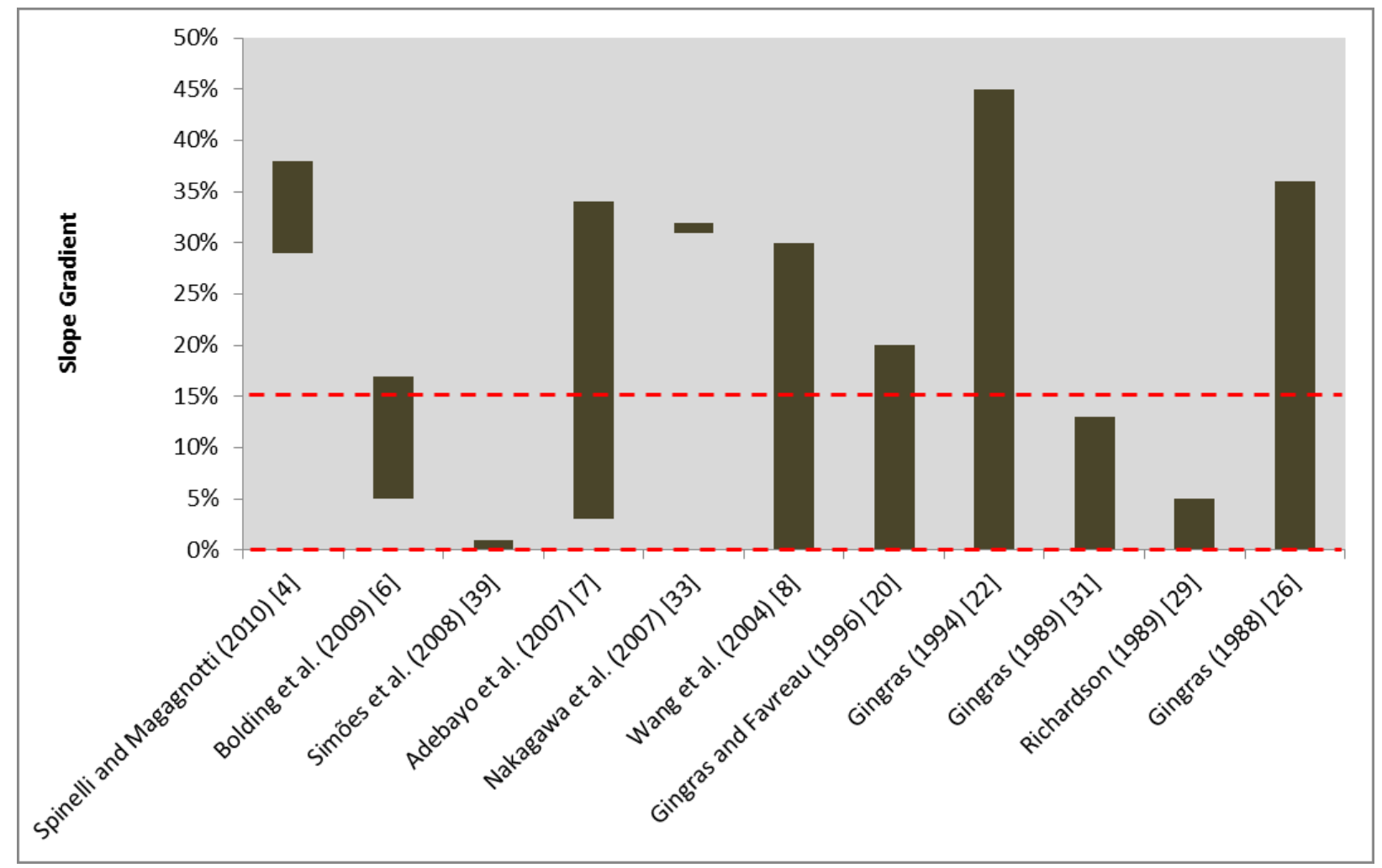

\subsection{Prescription}

Harvest prescriptions included in the reviewed literature can be grouped into four classes: (1) clear cut; (2) thinning; (3) partial harvest; and (4) shelterwood cut. Li et al. [27] conducted a simulation of different harvesting methods and reported that prescription is one factor that influences harvesting equipment productivity. They reported that a whole-tree system was the most productive and cost effective system when harvesting small diameter hardwood stands under the simulated conditions. Further, they reported that clear cutting was the most productive and shelterwood cut the least productive prescription. Several authors reported that their studies were conducted in clear-cuts [5,8,17,20,27,30,38], however, some of them also included other prescriptions in their studies [5,8,27,38]. Shelterwood cut has been reported by Glöde [19] as the only prescription studied. We acknowledge that there are several intensities and stages of a shelterwood cut. Because there is not always information about the stage of the shelterwood cut available, looking up stand density and stem size information in Tables 4 and 5, and Figures 2 and 3 will give an indication of the shelterwood stage (initial, intermediate, or final entry). Most studies that reported shelterwood or partial cut also reported other prescriptions [8,27]. Fifty percent of the forestland harvested in Maine in 2011 was partially harvested, while $43 \%$ of the harvested area was treated as a shelterwood (initial, intermediate, and final entry) [14]. Less than $6 \%$ of the area harvested was clear-cut, which sets the focus of research in Maine towards partial harvests and shelterwood cuts. 
Differences within silvicultural prescriptions are more obvious within thinning treatments. Spinelli et al. [4] reported a thinning in Norway spruce plantations in the Italian Alps in which approximately $50 \%$ of the initial trees were removed. This is a high intensity entry when compared to a thinning with a $20 \%$ removal by Nakagawa et al. [33]. Several studies described their prescription in terms of basal area removal. Removal intensities of $35 \%$ and $40 \%$ of the basal area in thinnings have been reported by Bolding et al. [6] and Ovaskainen et al. [28], respectively. Holtzscher and Lanford [35] reported that they used a fifth row and ninth row pattern in their study and thinned the stand to a target basal area of $15 \mathrm{~m}^{2} /$ ha. Removal intensities observed by the authors in Maine range from a basal area removal of $15 \%$ to $67 \%$. The target basal area includes a wide range from $7 \mathrm{~m}^{2} /$ ha to $48 \mathrm{~m}^{2} /$ ha. Table 6 shows a summary of silvicultural prescriptions and authors who carried out these prescriptions in their studies. The majority of the studies reviewed took place in clear cuts, whereas fewer studies were conducted in thinnings. The productivity within each prescription class varies from $13 \mathrm{~m}^{3} / \mathrm{PMH}$ up to $120 \mathrm{~m}^{3} / \mathrm{PMH}[18,24]$. Due to the majority of forest land in Maine harvested as partial harvests or shelterwood cuts the studies focusing on thinnings, partial harvest, and shelterwood cuts are of special interest. Clear cuts are not common to Maine and using productivity data from studies conducted in clear cuts will result in over estimation of productivity in prescriptions typical to Maine. However, harvesting clear cuts is not always more productive than havesting in thinnings. Légère and Gingras [18] reported harvest productivities in cleat cuts with 21.9 to $25.0 \mathrm{~m}^{3} / \mathrm{PMH}$, while Bolding et al. [6] have a productivity of $39.9 \mathrm{~m}^{3} / \mathrm{PMH}$ in thinnings. This difference in productivity is caused by multiple factors. The stand density of Légère and Gingras [18] was 1700 merchantable stems $(\mathrm{dbh}>10 \mathrm{~cm})$ per ha, with a regeneration density of 51,500 trees/ha, and a basal area of $27.5 \mathrm{~m}^{2} /$ ha. Bolding et al. [6] reported a stand density of 395 merchantable trees with a total of 1735 trees per ha, and a basal area of $33.5 \mathrm{~m}^{2} /$ ha. The fewer trees of Bolding et al. [6] represent a higher basal area with a larger tree volume than the study by Légère and Gingras [18]. Also, Légère and Gingras [18] paid special attention not to damage residual trees of $10 \mathrm{~cm}-12 \mathrm{~cm}$ in diameter, which decreased the harvesting productivity.

Table 6. Silvicultural prescriptions of harvesting equipment productivity studies.

\begin{tabular}{cccc}
\hline Clear cut & Thinning & $\begin{array}{c}\text { Partial \& } \\
\text { shelterwood cut }\end{array}$ & Selective cut \\
\hline Andersson and Evans & Bolding et al. (2009) [6] & Glöde (1999) [19] & Kluender et al. (1997) [38] \\
(1996) [24] & Holtzscher and Lanford & Wang et al. (2004) [8] & Spinelli et al. (2010) [3] \\
Kluender et al. (1997) [38] & (1997) [35] & & \\
Gingras and Favreau & Nakagawa et al. (2007) [33] & & \\
(1996) [20] & & \\
Legere and Gingras & Ovaskainen et al. (2004) [28] & \\
(1998) [18] & Spinelli and Magagnotti & & \\
Richardson and & (2010) [4] & & \\
Makkonnen (1994) & Spinelli et al. (2010) [3] & \\
Spinelli et al. (2010) [3] & & \\
Spinelli et al. (2007) [5] & Spinelli et al. (2007) [5] & \\
Wang et al. (2004) [8] & &
\end{tabular}




\section{Operator as an Influential Factor of Productivity}

Various studies have been conducted regarding the operator effect on harvesting equipment productivity. Several studies are concerned about the effect of harvester operators on productivity and time consumption. Others report the general aspects of the operator effect and its definition as well as its statistical analysis. Spinelli et al. [5] reported that the productivity of logging equipment depends on the skills of the operator. Including the operator effect into statistical analysis of equipment productivity is becoming more common in recent studies and therefore deserves a separate section in this paper.

\subsection{Operator Effect on Machine Productivity}

Ovaskainen et al. [28] found that the operator has a larger effect on harvesting equipment productivity than the stand structure. They believed that differences in operator productivity originates from cutting technique, motoric skill, work planning, experience, felling order, machine properties and the surrounding environment. They identified terrain as an important factor in operator performance and they chose operators for their study from different logging companies with similar experience with on-board computer systems. The comparability of the operators was good due to the fact that harvesting conditions (such as terrain, stand and tree characteristics and weather conditions) were similar during the study. They reported that the work technique is only one influential factor for processor productivity. With changing harvesting environments the capability of the operator to plan and apply his motoric skills in different situations needs to be emphasized. Further, they reported that productivity levels between harvester operators vary significantly, by up to $40 \%$ in similar stands. This number coincides with the results of Kärhä et al. [42] who reported a difference between operators using the same machine as great as $40 \%$. Compared to the several years of experience of the operators in Ovaskainen et al. [28] study, the operators in Kärhä et al. [42] study had at least three years' experience in thinning work. Lindroos [43] observed 12 experienced workers working with two firewood splitting systems. Results of that study show that the operator has a great influence on productivity.

\subsection{Operator Effect on Time Consumption}

Lindroos [44] investigated the differences between operators in terms of their effect on time consumption. The result of this study was that there were no significant interactions between operator and machine or wood class. He also points out that it has been argued that operators perform above their normal level when studied, especially in the first days. This statement can be traced back to Makkonen [45] whose data showed short working cycle times on the first day of the study that were never met again during the time of the study. He explained the short working times with the need of the observed worker to show his abilities and therefore work at a faster pace. He further highlights that some workers, when observed, work at a slower pace than usual. His explanation for this phenomenon is the fear of the worker that the work study will be used to cut the wage rate. Makkonen [45] also mentioned that these situations do not last as long as the first day and that afterwards the workers return to their normal speed. To account for the influence of the observer in his study, he disregarded the first day of time study completely. 
The importance of experienced operators in studies following the approach of Lindroos [43] and Brown et al. [36] can be seen in the study of Purfürst [34]. He reported that the difference between less trained and well-experienced harvester operators can be very high. He also reported that operators reach the end of their learning curve after nine months, and that this confirms previous assumptions that the end of the learning curve is reached within the range of 1000 productive machine hours (PMH) to $1500 \mathrm{PMH}$. Purfürst [34] did not find any significant correlation between the performance level of the operator and non-productive time such as repair time, but acknowledged that motivation and physical condition can affect changes in the operator performance over time.

\subsection{Statistical Analysis of the Operator Effect}

Lindroos [43] reported that treating the operator as a component of the random error is not appropriate due to the normally large operator effect and the small number of operators usually examined in forestry time studies. He reported that the prediction of harvester productivity for a population of operators is possible; however, a large variation between individual operators still remains. Ovaskainen et al. [28] and Kärhä et al. [42] reported a variation of productivity between different operators of up to $40 \%$. Operators with homogeneous demographic variables and work experience in the study of Lindroos [43] still resulted in a large variation in productivity among them. He suggested leaving the individual level assumptions behind and start analyzing data on a population level. This approach has also been described by Brown et al. [36] who reported that the operator effect can be reduced by conducting trials of multiple operators and machines or combining study results to create generalized productivity models. Using a large number of experienced operators for their studies has been carried out by Purfürst and Lindroos [46] and Spinelli et al. [3].

Spinelli et al. [3] data consisted of 19 different professional operators, generally experienced and proficient. They did not attempt to normalize individual performance, recognizing that all kinds of normalization or correction can introduce new sources of errors as outlined by Gullberg [47]. Gullberg [47] evaluated the operator-machine interaction using an approach of introducing a new variable "Adaptation". In that study the approach worked well but Gullberg's conclusion was that this approach needs to be tested further. He also reported that new error sources and uncontrolled variation in data can be introduced with all kinds of normalization and corrections. His conclusion is that in order to justify the normalization or correction of data the total unexplained variation must be significant. This once more suggests using the approach of Lindroos [44] and Brown et al. [36] to leave the analysis of individual performance and analyze data of multiple experienced operators on the population level.

\section{Study Designs and Data Collection}

The study carried out by Eggers et al. [32] identified an area with a wide distribution of diameter, height and form for their study. Within the area they selected trees and marked them with numbers. Each numbered tree had dbh and height measured using a measuring tape and a vertex hypsometer. They further sprayed an identification number on the base of each felled tree. Glöde [19] used a similar approach in measuring dbh and marking all trees in the treatment unit. 
Björheden [48] reported that the most common practice of work measurement is time study and that it is used worldwide to determine the input of time in the production process. He further describes four goals of time studies: (1) improvement of work organization and planning; (2) control and follow-up of operations; (3) improvement and comparison of working methods, tools and machinery; (4) to create data for performance and cost calculations. Björheden [48] also laid out the general definitions for time studies: work task, work element, work cycle, work object and work piece in context with comparing studies internationally.

There is a variety of data collection techniques reported in all the studies (Table 7). Glöde [19] used the time study software SIWORK3 and a Husky Hunter computer to collect time study data while Ovaskainen et al. [28] used a stop-watch design to gather cycle time data. Purfürst [34] used cycle time data collected by field crews to evaluate data collected through on-board computers. Lanford and Stokes [21] used video cameras to record cycle times, terrain and work conditions. Bolding et al. [6] videotaped 10 hours of feller-buncher activity to analyze the performance. A video camera approach was also used by Nurminen et al. [40]. Coup [49] used two video cameras, one in the cab and one outside, to record machine movements, and the time study software UMTPlus (Laubrass Inc., Montreal, QC, Canada) to conduct a post-harvest cycle time analysis.

Table 7. Summary of data collection methods used in previous timber harvesting studies.

\begin{tabular}{cccc}
\hline Video & On-board computer & Stop watch & Simulation \\
\hline Lanford and Stokes & Lanford and Stokes & Glöde (1999) [19] & Li et al. (2006) [27] \\
$(1996)[21]$ & $(1996)[21]$ & Ovaskainen et al. & Wang and LeDoux \\
Nurminen et al. & Nurminen et al. & $(2004)[28]$ & (2003) [50] \\
(2006) [40] & $(2006)[40]$ & Purfürst (2010) [34] & \\
& Purfürst (2010) [34] &
\end{tabular}

Many studies used further information from the on-board computers of the harvesting equipment. Lanford and Stokes [21], for example, used the harvester on-board computer to record productive time and number of trees. Purfürst [34] used the on-board data logging systems of the processor and validated the data with additional information from time studies on site. Nurminen et al. [40] extracted stem files from the machines either as printed versions or saved on diskette and associated the data with the recorded video. The reason for using the stem files was that Nurminen et al. [40] saw the exploitation of the stem files as more efficient and accurate than performing pre-harvest measurements of the sample trees. Eggers et al. [32] reported that there is no significant difference between manual and machine measurements. A recent study of Brown et al. [36] reports that the productivity calculated using on-board computer data of a processor does not significantly differ from calculations based on time and motion studies, supporting the results of Eggers et al. [32].

Li et al. [27] performed a felling simulation on a 1-acre plot which was replicated 36 times using existing productivity information. This approach has been used before by Wang and LeDoux [50] who published similar results in terms of the most productive system. Wang and LeDoux [50] used several existing models for chainsaw felling, feller-buncher, harvester, grapple skidder, and forwarder to validate their simulation (e.g., [38]). Rather than using a simulation, Spinelli et al. [3] produced a general 
productivity model for harvesters and processors in Italy using more than 15,000 individual time study records from previous studies between 1998 and 2008 conducted by the same principal investigator.

\section{Model Validation}

Howard [51] elaborated that researchers often ignore model validation or at least did not present validation procedures in publications. He reported that without documented model validation the utilization of productivity equations is questionable. Further, he introduced a method for validating productivity models using shift-level production data. He also reported that collecting time study data from the same study sites after establishing the model to validate the model would be the best method to use but is often too time consuming or too expensive. Howard [51] recommended the use of shift-level data with the reasoning that in most cases the data is already available from previous harvests within the company.

Adebayo et al. [7] validated their model using 70\% of the collected data to develop their model and $30 \%$ to compare the predicted and observed values. This approach is close to the one described by Howard [51]. Adebayo et al. [7] tested for 95\% significance and correlated the predicted values to the measured values to produce the validated $\mathrm{r}^{2}$. They used a two-sample $t$-test to test for the difference between the predicted values and the observed average cycle time. Spinelli et al. [3] described their validation process in detail in conjunction with Adebayo et al. [7] and Howard [51]. Their result is that there is no significant difference between the predicted and real values and therefore their model is accepted as valid. Spinelli et al. [3] further compared their model to already existing models from Sweden, Finland and Germany to show the differences of these models to their model and therefore underlined the necessity of their study to develop a model for Italy.

\section{Discussion}

This review of harvesting productivity studies over the last 25 years clearly highlights key differences in machine-level productivity resulting from equipment specifications, stand and operating conditions, operator performance, and even experimental designs and data collection methods. Harvesting equipment from the reviewed studies seldom represents makes/models commonly used in Maine and several of the studies reviewed did not even provide detailed specifications. The greater the differences in machine specifications, such as power class or bunk size which are known to affect equipment productivity, the less applicable those studies are to Maine. Further, several of the reviewed studies were conducted with maximum skidding/forwarding distances of less than $400 \mathrm{~m}$. Observations of logging operations in Maine by the authors, however, revealed that maximum skidding and forwarding distances of $800 \mathrm{~m}$ and $650 \mathrm{~m}$, respectively, are common.

With respect to stand and operating conditions, stem size is one of the most often cited factors influencing machine level productivity. As such, the range of stem sizes (either dbh or volume) included in a given study is important to consider before applying productivity models in other regions. There is an increased effort in Maine to thin stands with stem size ranging from $10 \mathrm{~cm}$ to $33 \mathrm{~cm}$, so a close examination of Figure 2 shows that approximately half of the studies that provided stem size information are of limited applicability in Maine. A similar problem exists for stand density and regeneration strategy. For example, 8 of the studies shown in Figure 3 were well below 1000 stems 
per hectare which is in contrast to stand densities up to 4800 stems per hectare projected to be thinned in Maine. These high density stands are due in part to the natural regeneration strategy in this state.

Finally, the skill of operators plays a vital role in harvesting productivity. Most harvesting productivity studies make reference to the experience level of the operators (e.g., number of years or hours of operation) unless the purpose of the study is to document the learning curve associated with that machine or operator. Due to the high level of mechanization in Maine's logging industry, operator proficiency is not expected to be a limiting factor in applicability of harvesting models from other regions.

An examination of all of the studies reviewed reveals that only seven meet the criteria of stem size and stand density of interest in Maine [3,5,6,23,26,29,35]. Of these only three actually harvest some of the tree species common to this region $[3,26,29]$. Two of those studies are from eastern Canada and were conducted in the late 1980s [26,29]. The machines included in those studies are now out of production. Further, the study by Gingras [26] consisted of two feller-bunchers with shear-heads which are not even used in Maine anymore. The most relevant study to Maine's logging industry in terms of stand and operating conditions turns out to be from Italy [3] and is based on cycle time data collected over many years, but the obvious limitation is due to the small number of common tree species between Maine and Italy. Clearly, these results suggest that Maine's logging industry and research community need to develop machine-level productivity equations specific to the state.

\section{Conclusions}

This review highlights key differences among harvesting productivity studies which will help forest operations researchers in other regions to design and implement their own studies by guiding them through major points of interest from several publications over the past 25 years. This review also questions the applicability of the existing studies to Maine's logging industry and builds a strong case for the need of increased forest operations research in the state. Productivity equations for harvesting equipment (whole-tree and cut-to-length) commonly used in Maine, need to be developed for the state's unique stand and operating conditions. This could even be expanded to include a feasibility assessment of harvesting on slopes greater than $40 \%$ in the more mountainous terrain of western Maine. Multiple operators should be included in each of these research efforts to account for the variation in operator performance. Finally, it is important to remember that individual machine productivity is not the only consideration for operation managers. Rather, the entire harvest system must be analyzed together. This requires identification of the bottleneck in production and often results in a tradeoff of increased production and machine utilization. For example, the use of one skidder might not be enough to fully utilize a delimber, however, the skidder utilization is rather high. When considering a second skidder, the delimber productivity will increase, but the skidders will not be fully utilized.

\section{Acknowledgments}

We would like to thank the Cooperative Forestry Research Unit (CFRU) and the Maine Agricultural and Forest Experiment Station (MAFES) in Maine for funding this research. We would also like to 
thank Robert Seymour and Aaron Weiskittel for their input and help with this project. Maine Agricultural and Forest Experiment Station Publication Number 3331.

\section{Conflicts of Interest}

The authors declare no conflict of interest. The authors are not affiliated with any equipment manufacturers and only included manufactures for better comparison of equipment models.

\section{References}

1. Forbig, A.; Büttner, I.; Emmerich, T. KWF-Tagung 2012: Die Fachexkursion. Available online: http://www.forstpraxis.de/kwf-tagung-2012-fachexkursion (accessed on 20 December 2012).

2. WG3 Group. Development and Harmonisation of New Operatonal Research and Assessment Procedures for Sustainable Forest Biomass Supply. Presented at WG3: Machine Cost Calculation and Data Analysis Methodologies, Berlin, Germany, 29 January 2010.

3. Spinelli, R.; Hartsough, B.R.; Magagnotti, N. Productivity standards for harvesters and processors in Italy. For. Prod. J. 2010, 60, 226-235.

4. Spinelli, R.; Magagnotti, N. Comparison of two harvesting systems for the production of forest biomass from thinning of Picea abies plantations. Scand. J. For. Res. 2010, 25, 69-77.

5. Spinelli, R.; Cuchet, E.; Roux, P. A new feller-buncher for harvesting energy wood: Results from a European test programme. Biomass Bioenergy 2007, 31, 205-210.

6. Bolding, M.C.; Kellogg, L.D.; Davis, C.T. Productivity and costs of an integrated mechanical forest fuel reduction operation in southwest Oregon. For. Prod. J. 2009, 59, 35-46.

7. Adebayo, A.B.; Han, H.-S.; Johnson, L. Productivity and cost of cut-to-length and whole-tree harvesting in a mixed-conifer stand. For. Prod. J. 2007, 57, 59-69.

8. Wang, J.; Long, C.; McNeel, J. Production and cost analysis of a feller-buncher and grapple skidder in central Appalachian hardwood forests. For. Prod. J. 2004, 54, 159-167.

9. Brinker, R.W.; Kinard, J.; Rummer, B.; Lanford, B.L. Machine Rates for Selected Forest Harvesting Machines, Circular 296(revised); Alabama Agricultural Experiment Station: Auburn, AL, USA, 2002; pp. 1-32.

10. Holzleitner, F.; Stampfer, K.; Visser, R. Utilization rates and cost factors in timber harvesting based on long-term machine data. Croat. J. For. Eng. 2011, 32, 501-508.

11. Stone, I.J.; Benjamin, J.G.; Leahy, J. Applying innovation theory to maine's logging industry. J. For. 2011, 109, 462-469.

12. North East State Foresters Association. The Economic Importance and Wood Flows from Maine's Forests, 2007; North East State Foresters Association: Concord, NH, USA, 2007; p. 8.

13. McCaskill, G.L.; McWilliams, W.H.; Barnett, C.J.; Butler, B.J.; Hatfield, M.A.; Kurtz, C.M.; Morin, R.S.; Moser, W.K.; Perry, C.H.; Woodall, C.W. Maine's Forests 2008; Resource Bulletin NRS-48; U.S. Department of Agriculture Forest Service, Northern Research Station: Newtown Sqaure, PA, USA, 2011; pp. 1-68.

14. Maine Forest Service. 2011 Silvicultural Activities Report; Silvicultural Activities Report; Department of Agriculture, Conservation and Forestry-Maine Forest Service-Forest Policy and Management Division: Augusta, ME, USA, 2013; p. 8. 
15. Leon, B.; Benjamin, J.G. A survey of business attributes, harvest capacity and equipment infrastructure of logging businesses in the northern forest. In the Northern Forest Logging Industry Assesment; University of Maine: Orono, ME, USA, 2013; p. 29.

16. McWilliams, W.H.; Butler, B.J.; Caldwell, L.E.; Griffith, D.M.; Hoppus, M.L.; Laustsen, K.M.; Lister, A.J.; Lister, T.W.; Metzler, J.W.; Morin, R.S.; et al. The Forests of Maine: 2003; Resource Bulletin NE-164; U.S. Department of Agriculture Forest Service, Northeastern Research Station: Newton Square, PA, USA, 2005; p. 188.

17. Jiroušek, R.; Klvač, R.; Skoupý, A. Productivity and costs of the mechanized cut-to-length wood harvesting system in clear-felling operations. J. For. Sci. 2007, 53, 476-482.

18. Légère, G.; Gingras, J.-F. Evaluation of Methods of Harvesting with Protection of Small Merchantable Stems; Technical Report-124; Forest Engineering Research Institute of Canada (FERIC): Pointe Claire, PQ, Canada, 1998; p. 12.

19. Glöde, D. Single- and double-grip harvesters-Productive measurements in final cutting of shelterwood. Int. J. For. Eng. 1999, 10, 63-74.

20. Gingras, J.-F.; Favreau, F.E. Comparative Cost Analysis of Integrated Harvesting and Delivery of Roundwood and Forest Biomass; Special Report SR-111; Forest Engineering Research Institute of Canada (FERIC): Pointe Claire, PQ, Canada, 1996; p. 18.

21. Lanford, B.L.; Stokes, B.J. Comparison of two thinning systems. Part 2. Productivity and costs. For. Prod. J. 1996, 46, 47-53.

22. Gingras, J.-F. A Comparison of Full-Tree versus Cut-to-Length Systems in the Manitoba Model Forest; Special Report SR-92; Forest Engineering Research Institute of Canada (FERIC): Pointe Claire, PQ, Canada, 1994; p. 16.

23. Han, H.-S.; Lee, H.W.; Johnson, L.R. Economic feasibility of an integrated harvesting system for small-diameter trees in southwest Idaho. For. Prod. J. 2004, 54, 21-27.

24. Andersson, B.; Evans, C.M. Harvesting Overmature Aspen Stands in Central Alberta; Special Report SR-112; Forest Engineering Research Institute of Canada (FERIC): Pointe Claire, PQ, Canada, 1996; p. 42.

25. Phillips, E.J. Comparison of Conventional and Mechanical Harvesting for the Prince Albert Model Forest; Special Report SR-121; Forest Engineering Research Institute of Canada (FERIC): Pointe Claire, PQ, Canada, 1997; p. 17.

26. Gingras, J.-F. The Effect of Site and Stand Factors on Feller-Buncher Performance; Technical Report TR-84; Forest Engineering Research Institute of Canada (FERIC): Pointe Claire, PQ, Canada, 1988; p. 18.

27. Li, Y.; Wang, J.; Miller, G.; McNeel, J. Production economics of harvesting small diameter hardwood stands in central Appalachia. For. Prod. J. 2006, 56, 81-86.

28. Ovaskainen, H.; Uusitalo, J.; Väätäinen, K. Characteristics and significance of a harvester operators' working technique in thinnings. Int. J. For. Eng. 2004, 15, 67-77.

29. Richardson, R. Evaluation of Five Processors and Harvesters; Technical Report TR-94; Forest Engineering Research Institute of Canada (FERIC): Pointe Claire, PQ, Canada, 1989; p. 18.

30. Richardson, R.; Makkonen, I. The Performance of Cut-to-Length Systems in Eastern Canada; Technical Report TR-109; Publisher: Pointe Claire, PQ, Canada, 1994; p. 16. 
31. Gingras, J.-F. Feller-Buncher Performance in Adverse Stand and Terrain Conditions; Technical Report TR-89; Forest Engineering Research Institute of Canada (FERIC): Pointe Claire, PQ, Canada, 1989; p. 10.

32. Eggers, J.; McEwan, A.; Conradie, B. Pinus saw timber tree optimization in South Africa: A comparison of mechanised tree optimisation (harvester/processor) versus current manual methods. South. For. 2010, 72, 23-30.

33. Nakagawa, M.; Hamatsu, J.; Saitou, T.; Ishida, H. Effect of tree size on productivity and time required for work elements in selective thinning by a harvester. Int. J. For. Eng. 2007, 18, $24-28$.

34. Purfürst, F.T. Learning curves of harvester operators. Croat. J. For. Eng. 2010, 31, 89-97.

35. Holtzscher, M.A.; Lanford, B.L. Tree diameter effects on cost and productivity of cut-to-length systems. For. Prod. J. 1997, 47, 25-30.

36. Brown, M.; Strandgard, M.; Acuna, M.; Walsh, D.; Mitchell, R. Improving forest operations management through applied research. Croat. J. For. Eng. 2011, 32, 471-480.

37. Hiesl, P.; Benjamin, J.G. A multi-stem feller-buncher cycle time model in partial harvests in small diameter wood stands. Int. J. For. Eng. 2013, 24, 101-108.

38. Kluender, R.; Lortz, D.; McCoy, W.; Stokes, B.J.; Klepac, J. Productivity of rubber-tired skidders in southern pine forests. For. Prod. J. 1997, 47, 53-58.

39. Simões, D.; Marcelino, F.A.; Pletsch, T.A.; de Faria, L.R.; Fenner, P.T. Technical and Economical Evaluation of Harvester Cut-to-Length System in First Cut Eucalyptus Forest. In Proceedings of CIGR International Conference of Agricultural Engineering; XXXVII Congresso Brasileiro De Engenharia Agricola-CONBEA, Iguassu Falls City, Brazil, 31 August to 4 September 2008.

40. Nurminen, T.; Korpunen, H.; Uusitalo, J. Time consumption analysis of the mechanized cut-to-length harvesting system. Silva Fenn. 2006, 40, 335-363.

41. Hiesl, P. Productivity Standards for Whole-Tree and Cut-to-Length Harvesting Systems in Maine. Master Thesis, School of Forest Resources, University of Maine, Orono, ME, USA, 2013; p. 150.

42. Kärhä, K.; Rökkö, E.; Gumse, S.-I. Productivity and cutting costs of thinning harvesters. Int. J. For. Eng. 2004, 15, 43-56.

43. Lindroos, O. Scrutinizing the theory of comparative time studies with operator as a block effect. Int. J. For. Eng. 2010, 21, 20-30.

44. Lindroos, $\mathrm{O}$. The effects of increased mechanization on time consumption in small-scale firewood processing. Silva Fenn. 2008, 42, 791-805.

45. Makkonen, O. Metsätöiden vertailevan aikatutkirnuks- periaate. Summary: The principle of comparative time studies in forest work. Acta For. Fenn. 1954, 61, No. 14.

46. Purfürst, F.T.; Lindroos, O. The correlation between long-term productivity and short-term performance ratings of harvester operators. Croat. J. For. Eng. 2011, 32, 509-519.

47. Gullberg, T. Evaluating operator-machine interactions in comparative time studies. Int. J. For. Eng. 1995, 7, 51-61.

48. Björheden, R. Basic time concepts for international comparisons of time study reports. Int. J. For. Eng. 1991, 2, 33-39. 
49. Coup, C.E. A Case Study Approach for Assessing Operational and Silvicultural Performance of Whole-Tree Biomass Harvesting in Maine. Master Thesis, School of Forest Resources, University of Maine, Orono, ME, USA, 2009; pp. 1-168.

50. Wang, J.; LeDoux, C.B. Estimating and validating ground-based timber harvesting production through computer simulation. For. Sci. 2003, 49, 64-76.

51. Howard, A.F. Validating forest harvesting production equations. Trans. Am. Soc. Agric. Eng. 1992, 35, 1683-1687.

(C) 2013 by the authors; licensee MDPI, Basel, Switzerland. This article is an open access article distributed under the terms and conditions of the Creative Commons Attribution license (http://creativecommons.org/licenses/by/3.0/). 